UDC 621.396.1

\title{
ANALYSIS OF SPATIAL-TIME CHARACTERISTICS OF A RADIO LINE WITH MULTIPATH WITHIN 5G TECHNOLOGY
}

\author{
Leonid O. Uryvsky, Valeriia Y. Solianikova \\ Igor Sikorsky Kyiv Polytechnic Institute, Kyiv, Ukraine
}

Background. As a result of the reflection of rays from buildings, from the surface of the Earth or from horizontal boundaries between different layers of the atmosphere, multipath effects occur that cause fast fading, which affects the quality of service.

Objective. Determine the spatial-time parameters of the directly received and reflected signals for the conditions of conducting wireless communications specific to $5 \mathrm{G}$ technology.

Methods. The delay time of the beam reflected from the obstacle with respect to the direct beam at the receiving point and the transmission rate of the streams for different frequency ranges are calculated.

Results. For the $900 \mathrm{MHz}, 2.4 \mathrm{GHz}$, and $5 \mathrm{GHz}$ ranges, the maximum delay of the reflected beam, at which the end of the main signal coincides with the moment of arrival of the reflected beam, corresponds to the transmission rates of the streams $1.1,1.2$, and $1.34 \mathrm{Mbps}$, respectively.

Conclusions. A technique is proposed for determining the spatio-time parameters received directly and reflected signals for the conditions of conducting wireless communications, typical for 5G technology.

Keywords: multipath; 5G; 4G; LTE; Cassini Oval; OFDM.

\section{Introduction}

5G technology is characterized by a small distance between subscribers and base stations $(500-1000 \mathrm{~m})$ and relatively high frequencies for communication $(2-5 \mathrm{GHz})$ [1].

When the distance between subscribers and base stations is very small, usually only a direct ray arrives at the receivers, but when the distance increases, more obstacles appear on the ray path and more factors arise for its reflection [2].

If the ray, which was delayed after reflection from the obstacle, arrives at the receiving point after registering the symbol transmitted from the emitting station, then it is overlap on neighboring symbols and destroys them, because the delay time of the ray is longer than the pulse duration of the signal. And, the higher the signal transmission speed, the shorter the pulse, and the more difficult it is to distinguish between received signals distorted by reflected rays decorrelated with the signal.

\section{Formulation of the problem}

OFDM is a tool [3], which allows transmitting a common stream in such a way that the speed in each of $n$ subcarriers is $n$ times less, and, accordingly, the pulse length is $\mathrm{n}$ times longer. With a constant delay time of the reflected signal, an increase in the number of subcarriers makes this delay shorter than the pulse duration, and, therefore, the signal energy loss is determined only by its correlation function with the reflected ray. As the number of OFDM subcarriers increases, the value of the correlation function (with incoherent reception) tends to 1 .

Thus, having spatial characteristics in a particular channel, it is possible to select such a number of subcarriers at which the real delay time becomes much less than the pulse length and thereby improves the noise immunity of reception in multipath conditions.

The purpose of the article is to determine the spatial-time parameters of directly and reflected signals received for the conditions of conducting wireless communications, characteristic of $5 \mathrm{G}$ technology.

\section{The solution of the problem}

Consider a mobile communication channel in which a signal is transmitted from a transmitter (point A) to a receiver (point A1), which are located at a distance $\mathrm{R}$ from each other. Fig. 1 schematically shows two points A and A1 - the transmitter and receiver, respectively. The main signal arrives at point $\mathrm{A} 1$, but there are other signals that are reflected from nearby surfaces, i.e. the ray along the trajectory $\mathrm{R} 2$ is reflected from the circle at point $\mathrm{C}$ and also arrives at point A1. This is the response of the main signal, 
where the radius of the circle is much less than the path length.

At the same time, we consider that the circle is the boundary inside which all the signals that can be perceived at point A1 are located. Signals that are reflected outside this circle are lower than the sensitivity of the receiver and are not perceived as reflected rays, i.e. outside this area, obstacles and reflective surfaces have no effect on reception.

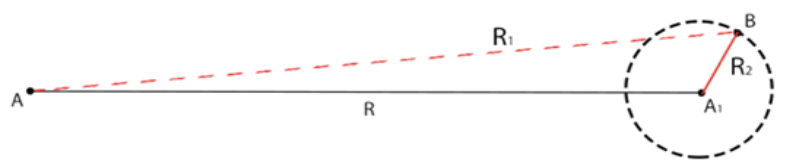

Fig. 1. Schematic representation of a communication line and a random reflected ray

The region of formation of reflected rays using a geometric shape in the form of Cassini ovals could be described using the mathematical model [2].

Cassini Oval is a curve that is a geometrical place of points, the product of the distances from which to two given points is constant and equal to the square of a certain number $a^{2}=R_{1} R_{2}$, and the distance between the points is $2 \mathrm{c}=\mathrm{R}$ [4].

Fig. 3 shows the four most characteristic variations in the shape of the zones of formation of reflected rays, depending on the parameters a and c.

In the first case (Fig. 2, a at $\mathrm{c} \geq 2$ ), the Cassini oval is actually an oval with foci at the locations of the receiving and transmitting stations. For $\mathrm{c}$ $<\mathrm{a}<\mathrm{c} \sqrt{2}$, the oval is more compressed in the middle of the path (Fig. 2, b).

In the third case, where $\mathrm{a}=\mathrm{c}-$ the reflection zone is a lemniscate (Fig. 2, c). Finally, when a $<\mathrm{c}$, the oval turns into a figure close in shape to a circle around the locations of the antennas (Fig. 2 d) [5].

Thus, Figure 1 is a special case of the Cassini oval, where the formation of the reflected ray for the case $\mathrm{a}<\mathrm{c}$ is more clearly demonstrated.

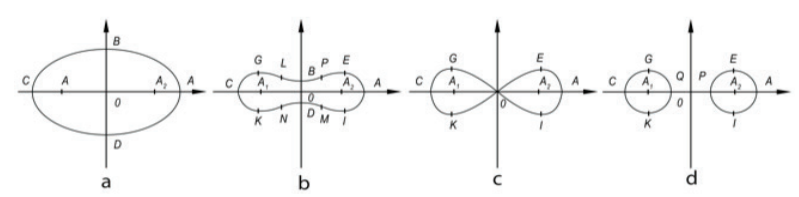

Fig. 2 Forms of zones of formation of reflected rays

Based on the ratios given in [2], we calculate the parameters a and c using real parameters for mobile communication between the base station and the mobile phone:

$$
\begin{gathered}
a=\sqrt{R_{1} R_{2}} \\
\sqrt{\left(h_{1}^{2}+h_{0}^{2}\right)\left(h_{2}^{2}+h_{0}^{2}\right) \sqrt{P_{1} G_{1} \eta_{1} b_{1} \eta_{2} \omega_{\mathrm{BX}} / U_{\mathrm{BX}}}}(1)
\end{gathered}
$$

where $\mathrm{h}_{1}=30 \mathrm{~m}-$ transmit antenna height,

$\mathrm{h}_{2}=2 \mathrm{~m}-$ average height for the mobile terminal,

$\mathrm{h}_{0}=5 \mathrm{~m}-$ minimum effective antenna height,

$\mathrm{P}_{1}=40 \mathrm{~W}-$ base station transmitter power,

$\mathrm{G}_{1}=18 \mathrm{dBi}=63,1$ - antenna gain,

$\eta_{1}=0.9-$ the efficiency of the system for transmitting energy from the transmitter to the transmitting antenna,

$\omega_{\mathrm{BX}}=75 \Omega$ - receiver input impedance,

$U_{\mathrm{BX}}=0.7 \mathrm{mV}-$ sensitivity of the receiver (mobile terminal).

Parameter $b_{1}$ - is the height of the obstacle located at a distance $\mathrm{R}_{1}$ from the mobile terminal (radius of the first Fresnel zone).

The task is to determine the area where the energy of the reflected signal exceeds the sensitivity of the receiver of the mobile terminal.

According to [2], $b_{1}$ can be determined from the dependence:

$$
b_{1}=\sqrt{(\lambda R / 3) k(1-k)}
$$

where $\quad \mathrm{R}=1 \mathrm{~km}-$ distance from transmitting to receiving antenna;

$\mathrm{k}=0,05$ - ratio of distances to obstacles and from transmitting to receiving antenna;

$\lambda$ - wavelength equal

$$
\lambda=\mathrm{C} / F,
$$

$\mathrm{C}=3 * 108-$ speed of light;

$\mathrm{F}=2.4 \mathrm{GHz}$ - frequency at which the signal is transmitted.

Using the initial parameters, we calculate the parameter $a$ provided that the distance between the receiving and transmitting devices is $1000 \mathrm{~m}$, and half of this distance is $\mathrm{c}=500 \mathrm{~m}$. Substituting all the values in formula (1), we obtain:

$$
a=\sqrt{R_{1} R_{2}}=\sqrt{122029,4}=349 \mathrm{~m} .
$$

So, with $\mathrm{c}=500 \mathrm{~m}, \mathrm{a}=349 \mathrm{~m}$, the Cassini oval takes the form of two separate circles $(\mathrm{a}<\mathrm{c})$ around the locations of the receiving and transmitting antennas (Fig. 2d), which is identical in shape to Fig. 1. 
Next, it should be calculated the delay time of the reflected signal relative to the time of arrival of the main ray.

For simplicity of calculation, assume that the method of processing the transmitted signal is incoherent.

Fig. 3 shows the sequence of pulses and their responses that arrive at receiver A1.

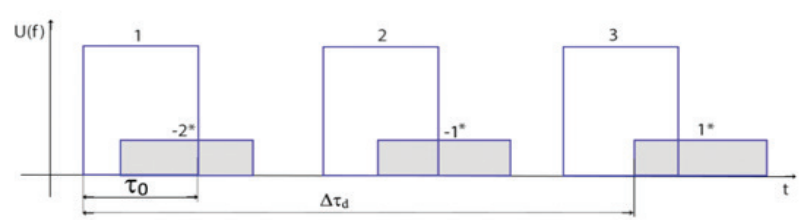

Fig. 3. Delayed signal response at the receiver

The time graph shows that the response of pulse 1 is late for the delay time $\Delta \tau_{\mathrm{d}}$ and overlaps pulse 3 , while the duration of the pulse itself is $\tau_{0}$ :

$$
\tau_{0}=1 / \mathrm{v}_{\mathrm{o}},
$$

where $\mathrm{v}_{0}-$ this is the symbol rate;

$$
\Delta \tau \mathrm{d}=\Delta \mathrm{r} / \mathrm{C},
$$

where $\Delta \mathrm{r}$ is the difference between the length of the path that the signal passes directly to the receiving point and the reflected response of the signal.

Fig. 4 shows a graph of the pulse 1 extended in time by $\mathrm{n}$ times and its response $1^{*}$, where the delay of the response from the main pulse remains the same $\Delta \tau_{\mathrm{d}}$, but the pulse duration becomes $\mathrm{n}$ times longer: $\tau_{1}$ $=n \tau_{0}-$ due to application OFDM technology, where $\mathrm{n}$ is the number of subcarriers.

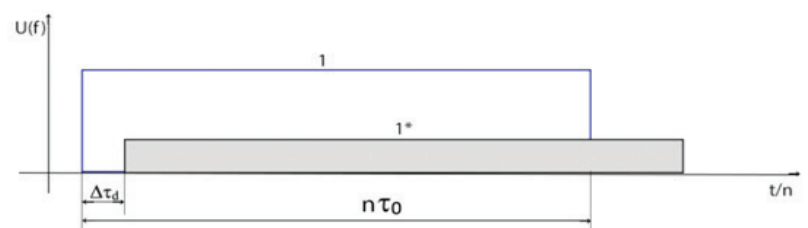

Fig.4. The delay in the response of the signal in the receiver, provided that the original signal is stretched $\mathrm{n}$ times

In order to calculate $\Delta \mathrm{r}$, for a start, we consider a particular case of the formation of a reflected signal from the boundary of a sphere in which the reflected rays are sensitive to the receiver.

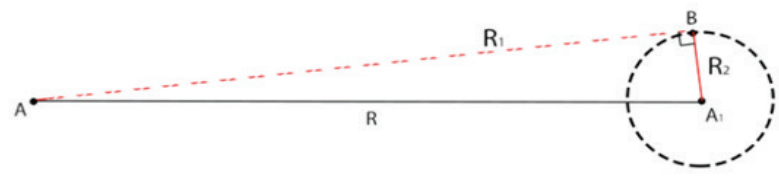

Fig. 5. Schematic representation of the communication line and the reflected beam (special case)

In Fig. 5, assume that $\mathrm{R}_{1}$ is a tangent to a circle, then it forms a right angle with the radius of the circle $\mathrm{R}_{2}$. Therefore, the triangle $\mathrm{AA}_{1} \mathrm{~B}$ can be considered as a rectangular one.

Then we calculate $R_{2}$ taking into account that:

$$
\begin{gathered}
\mathrm{R}=2 \mathrm{c}, \text { a } \mathrm{R}_{1} \mathrm{R}_{2}=\mathrm{a}^{2} . \\
\text { As } \mathrm{R}_{1}=\mathrm{a}^{2} / \mathrm{R}_{2}, \text { so } \mathrm{R}^{2}=\mathrm{R}_{1}{ }^{2}+\mathrm{R}_{2}{ }^{2} \\
4 \mathrm{c}^{2}=\mathrm{a}^{4} / \mathrm{R}_{2}{ }^{2}+\mathrm{R}_{2}{ }^{2} \\
\mathrm{R}_{2}{ }^{2}-4 \mathrm{c}^{2} \mathrm{R}_{2}{ }^{2}+\mathrm{a}^{4}=0
\end{gathered}
$$

The solution of the quadratic equation is the result:

$$
\begin{gathered}
\mathrm{R}_{2}=\sqrt{2 c^{2} \pm \sqrt{4 c^{4} a^{4}}}=122,96 \mathrm{~m} \\
\mathrm{R}_{1}=992.41 \mathrm{~m}
\end{gathered}
$$

The case in which the delay in the response of the signal will be maximum is shown in Fig. 6 . Then the signal will pass through the receiver, and its response, reflected from a certain surface, will fall back into the receiver, passing an additional distance of $2 \mathrm{R}_{2}$.

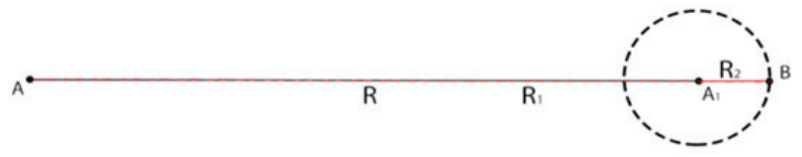

Fig. 6. Schematic representation of the communication line and the path of the reflected ray, which creates the maximum delay time

Then the difference between the length of the path that the response of the signal passes and the main signal is:

$$
\Delta r=2 R_{2}=245 \mathrm{~m} .
$$

Well then, the maximum delay of the response is equal to:

$$
\Delta \tau_{\mathrm{d}}=\Delta \mathrm{r} / \mathrm{C}=245 / 3 * 10^{8}=0,82 \mu \mathrm{s}
$$

\section{Analysis of the results}

We calculate the critical value of the symbol stream transmission speed $v_{\mathrm{cr}}$, at which the pulse duration $\tau_{0}$ coincides with the delay time $\Delta \tau_{\mathrm{d}}$ and compare the results for different frequency ranges:

$$
V_{\mathrm{cr}}=1 / \Delta \tau_{\mathrm{d}}
$$


Table 1. Comparison of the results of calculations of the pulse transmission rate for various frequency

$$
\text { ranges }
$$

\begin{tabular}{|l|l|l|l|}
\hline $\begin{array}{l}\text { Frequency } \\
\text { range }-F\end{array}$ & $\begin{array}{l}\text { The duration } \\
\text { of the delay } \\
\text { path }-\Delta r, \mathrm{~m}\end{array}$ & $\begin{array}{l}\text { Maximum } \\
\text { Response } \\
\text { Delay }- \\
\Delta \tau_{\mathrm{d}}, \mu \mathrm{s}\end{array}$ & $\begin{array}{l}\text { Pulse } \\
\text { rate } v_{c r}, \\
\text { Mbit/s }\end{array}$ \\
\hline $5 \mathrm{GHz}$ & 224,08 & 0,75 & 1,34 \\
\hline $2,4 \mathrm{GHz}$ & 245,93 & 0,82 & 1,22 \\
\hline $900 \mathrm{MHz}$ & 278,61 & 0,93 & 1,08 \\
\hline
\end{tabular}

As follows from the data of Table 1, when the radiation frequency changes 5.5 times $(0.9 \ldots 5$ $\mathrm{GHz}$ ), the difference in the maximum delay time is $24 \%(0.75 \ldots 0.93 \mu \mathrm{s})$. Therefore, changing the frequency range is not a significant factor in changing the delay time. As detailed calculations show, the communication range is a more sensitive factor.

\section{Conclusions}

Thus, a technique is proposed for determining the spatial-time parameters received directly and reflected signals for the conditions of conducting wireless communications, characteristic of $5 \mathrm{G}$ technology.

For the ranges of $900 \mathrm{MHz}, 2.4 \mathrm{GHz}$ and 5 $\mathrm{GHz}$, the expected maximum delay times of reflected rays are calculated for the same distance values between the subscriber and the base station. It is shown that the maximum delay of the reflected ray, at which the end of the duration of the main signal coincides with the moment of arrival of the reflected ray, corresponds to the transmission speed of the streams 1.1...1.35 Mbit/s.

The objective of the subsequent study is to calculate the recommended values of the number of subcarriers when using OFDM technology, as a means of reducing the influence of reflected rays on the quality of signal reception in multipath conditions on mobile communication lines of generations $4 \mathrm{G}$ and $5 \mathrm{G}$.

\section{References}

1. S.-Y. Lien et al. /5G New Radio: Waveform, Frame Structure, Multiple Access, and Initial Access. - IEEE Commun. Mag., vol. 55, no. 6, June 2017, pp. 64- 71.

2. Dorovskikh A.V., Uryvsky L.A., Lukhanin M.I. / A method for distributing on-site repeaters of a road transport control system / Automation and mechanization of control. - K .: UkrSRINTI, No. $1,1985 .-$ p. 60 ... 62.

3. Osypchuk S., Uryvsky L. / OFDM Signal Research with Varied Subcarriers Number/ Transport and Telecom-munications. - Latvia, ISSN 14076179, Vol. 17, №. 3, 2016, pp. $192 \ldots .201$

4. Sivardiere, J. / Kepler ellipse or Cassini oval? / European Journal of Physics. - 15(2), 1994, 6264. DOI:10.1088/0143-0807/15/2/004.

5. Weisstein, Eric W. / Cassini Ovals. / MathWorld. http://mathworld.wolfram.com/CassiniOvals.htm

Уривський Л.О., Солянікова В.Ю.

Аналіз просторово-часових характеристик радіолінії з многолучевостью в рамках технології 5 G

Проблематика. В результаті відбиття променів від будівель, від поверхні Землі або від горизонтальних кордонів між різними верствами атмосфери виникають багатопроменеві ефекти які спричиняють швидкі завмирання, що погіршує якість обслуговування.

Мета дослідження. Визначити просторово-часові параметри прийнятих безпосередньо і відбитих сигналів для умов ведення бездротового зв'язку, характерних для технології 5G.

Методика реалізації. Розраховується час запізнювання відбитого від перешкоди променя по відношенню до прямого променю в точці прийому і швидкість передачі потоків для різних діапазонах частот.

Результати дослідження. Для діапазонів 900 МГц, 2,4 ГГц і 5 ГГц максимальне запізнння відбитого променя, при якому закінчення тривалості основного сигналу збігається з моментом приходу відбитого променя, відповідають швидкості передачі потоків 1.1, 1.2, і 1.34 Мбіт / с відповідно.

Висновки. Запропоновано методику для визначення просторово-часових параметрів, що приймаються безпосередньо і відбитих сигналів для умов ведення бездротового зв'язку, характерних для технології 5G.

Ключові слова: багатопроміневість; 5G; 4G; LTE; овал Кассіни; OFDM. 
Урывский Л.А., Соляникова В.Ю.

Анализ пространственно-временных характеристик радиолинии с многолучевостью в рамках технологии 5G

Проблематика. В результате отражения лучей от зданий, от поверхности Земли или от горизонтальных границ между различными слоями атмосферы возникают многолучевые эффекты вызывающие быстрые замирания, что ухудшает качество обслуживания.

Цель исследования. Определить пространственно-временные параметры принимаемых непосредственно и отраженных сигналов для условий ведения беспроводной связи, характерных для технологии $5 \mathrm{G}$.

Методика реализации. Рассчитывается время запаздывания отраженного от препятствия луча по отношению к прямому лучу в точке приема и скорость передачи потоков для разных диапазонах частот.

Результаты исследования. Для диапазонов 900 МГц, 2,4 ГГц и 5 ГГц максимальное запаздывание отраженного луча, при котором окончание длительности основного сигнала совпадает с моментом прихода отраженного луча, соответствуют скорости передачи потоков 1.1, 1.2, i 1.34 Мбит/с соответственно.

Выводы. Предложена методика для определения пространственно-временных параметров, принимаемых непосредственно и отраженных сигналов для условий ведения беспроводной связи, характерных для технологии 5G.

Ключевые слова: многолучевость; 5G; 4G; LTE; овал Кассини; OFDM. 